ACTA THERIOLOGICA

Vol. $33,11: 131-137,1988$

\title{
Characteristics of the Reproductive Cycle of the Mole, Talpa europaea, in the Northeast of the Iberian Peninsula
}

CHARAKTERYSTYKA CYKLU ROZRODU KRETA TALPA EUROPAEA

W POENOCNO-WSCHODNICH REJONACH POEWYSPU IBERYJSKIEGO

\section{$M^{a}$ José LOPEZ-FUSTER, Joaquim GOSALBEZ \& Sara LLUCH}

López-Fuster Ma J., Gosàlbez J. \& Lluch S., 1988: Characteristics of the reproductive cycle of the mole, Talpa europaea, in the Northeast of the Iberian Peninsula. Acta theriol., 33, 11: 131-137. [With 3 Tables \& 2 Figs.]

The breeding season of Talpa europaea Linnaeus, 1758, in the NE of the Iberian Peninsula lasts from December to June, with maximum activity from January to March. Both males and females reach sexual maturity once they have completed their first year. The number of embryos per litter is neither connected with the age of the female nor the month of capture. The length breeding season in the area studied implies that some females may have two or even three litters per year under favourable conditions. The average number of embryos per female in the population, as a whole, is $3.12(n=17)$. The differences noted in comparison with other European populations can be attributed to the differing climatic conditions which are directly related to the timing of the breeding season.

[Dept. Biologiá Animal, Fac. Biologiá, Univ. Barcelona, Avgda. Diagonal 645, 08028-Barcelona, Spain].

\section{INTRODUCTION}

The mole, Talpa europaea Linnaeus, 1758, is found in most of Europe. In the Iberian Peninsula, however, it is limited to northeastern parts, from Cantabria (Santander) to the Catalan coast.

Due to its burrowing habits, it is difficult to keep it in captivity, and as a result very little is known about its breeding in the Iberian Peninsula. For this territory, there are only the data collected by Vericad (1970) in the Pyrenees of Huesca. Dates for the beginning and end of the reproductive period, the litter size and the number of litters per female in other European populations are reported by several authors such as Adams (1903-1909), Ognev (1928) Folitarek (1932), Balli (1940); Stein (1950), Godfrey (1956), Deanesly \& Allanson (1967) and Grulich (1967 a, b).

The purpose of the present study is to describe the characteristics of the reproductive cycle of Talpa europaea in the NE of the Iberian Peninsula. 


\section{MATERIAL AND METHODS}

The material analysed in the present study consisted of 180 moles (88 $\delta \hat{\sigma}$ and 92 ?) trapped during the period 1966-1985 (Tables 1, 2). Figure 1 presents the distribution of the sites prospected. The moles were captured in alpine and subalpine meadows and crop fields. These biotopes represent the optimal environments for the species, due to the consistency and structure of the soil and their general nature.

The sexual activity of the individuals was determined using the following criteria: for the males, the testicular length (TL), and cytological analysis of the testiele contents, using the Diff-Quick method (Gosalbez et al., 1979); for the females, the vulva condition, the degree of development and irrigation of the

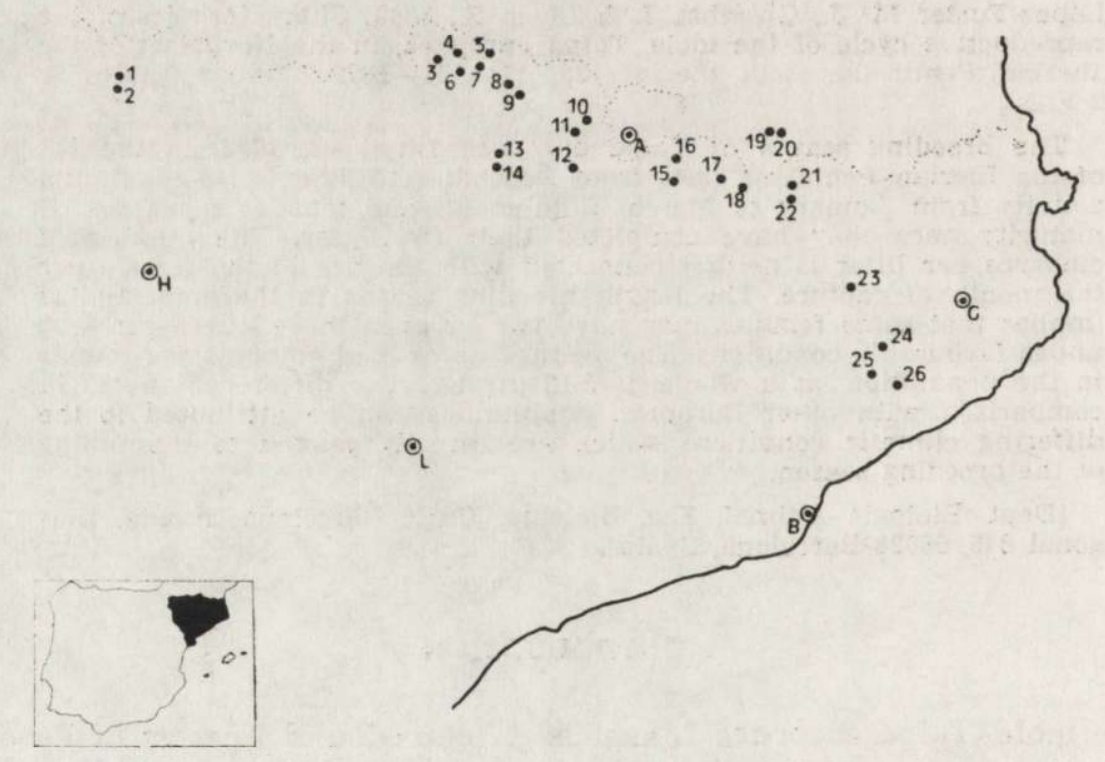

Fig. 1. Location of the different sites surveyed in the present study. 1. VillanúaCanfranc, 2. Borau, 3. Arrós-Aubert, 4. Barradós, 5. Montgarri, 6. Garós, 7. Pla de Beret, 8. Port de la Bonaigua, 9. Son del Pi, 10. Areu, 11. Ainet de Besan, 12. Six, 13. Cabdella, 14. Torre de Cabdella, 15. Martinet de Cerdanya, 16. Aransá, 17. Alp, 18. La Molina, 19. Odeillo, 20. Saint Pierre dels Forcats, 21. Queralbs, 22. Ribes de Freser, 23. Cantonigrós, 24. Sant Hilari de Sacalm, 25. Santa Fe del Montseny, 26. Breda.

uterus, the presence or absence of embryos and the development of the mammary glands. In the case of $T$. europaea, the term "dilated uterus" differentiates the mature females from the immature, but it does not indicate whether they are active or not. This is because, when the female reaches sexual maturity, the uterus becomes dilated and remains so for the rest of the animal's life (Stein, 1950).

Relative age was determined by the degree of tooth-wear (Grulich, 1967a). This permits the separation of six age-groups $(\mathrm{O}-\mathrm{V})$. According to his author, each 
age-group corresponds to one year of life, and juveniles are those found still in the nest. Sub-adults are those of age-group $\mathrm{O}$ and adults those of age-groups $\mathrm{I}-\mathrm{V}$.

\section{RESULTS AND DISCUSSION}

The results obtained from the degree of sexual activity throughout the year (Table 1) show that males do not reach sexual maturity until they are one year old: sub-adults (age-group 0) had testicle lengths

\section{Table 1}

Degree of sexual activity of the males of $T$. europaea in the NE of the Iberian Peninsula, plotted against age group $(0-V)$ and month of capture. * age group not established, inactive males: $\mathrm{TL}=4.0-9.9 \mathrm{~mm}$, active males: $\mathrm{TL}=10.0-15.4 \mathrm{~mm}$ ).

\begin{tabular}{|c|c|c|c|c|c|}
\hline Month & $N$ & Inactive & $n$ & Active & $n$ \\
\hline January & 4 & - & - & $\begin{array}{l}3 \text { (I) } \\
1 \text { (III) }\end{array}$ & 4 \\
\hline February & 14 & - & - & $\begin{array}{l}6 \text { (I) } \\
1 \text { (II) } \\
4(\mathrm{III}) \\
2(\mathrm{IV}) \\
1\left(^{*}\right)\end{array}$ & 14 \\
\hline March & 12 & $\begin{array}{l}1(0) \\
1(\mathrm{II})\end{array}$ & 2 & $\begin{array}{l}6 \text { (I) } \\
2 \text { (II) } \\
1 \text { (III) } \\
1 \text { (IV) }\end{array}$ & 10 \\
\hline April & 4 & $2(\mathrm{I})$ & 2 & $\begin{array}{l}1(\mathrm{I}) \\
1(\mathrm{~V})\end{array}$ & 2 \\
\hline $\begin{array}{l}\text { May } \\
\text { June }\end{array}$ & $\begin{array}{l}1 \\
1\end{array}$ & & $\begin{array}{l}1 \\
1\end{array}$ & $=$ & - \\
\hline July & 7 & $\begin{array}{l}2(0) \\
1(\mathrm{I}) \\
1(\mathrm{III}) \\
2 \text { (IV) } \\
1(\mathrm{~V})\end{array}$ & 7 & - & - \\
\hline August & 4 & $\begin{array}{l}1(0) \\
2(\mathrm{I}) \\
1(\mathrm{II})\end{array}$ & 4 & - & - \\
\hline September & 5 & $\begin{array}{l}4(\mathrm{I}) \\
1(\mathrm{II})\end{array}$ & 5 & - & - \\
\hline October & 8 & $\begin{array}{l}6(\mathrm{I}) \\
1(\mathrm{II}) \\
1\left(^{*}\right)\end{array}$ & 8 & - & - \\
\hline November & 20 & $\begin{array}{l}14(\mathrm{I}) \\
2 \text { (II) } \\
2 \text { (III) } \\
1(\mathrm{IV}) \\
1\left(^{*}\right)\end{array}$ & 20 & - & - \\
\hline December & 8 & $\begin{array}{l}1 \text { (I) } \\
2 \text { (II) } \\
1 \text { (III) } \\
1 \text { (IV) } \\
1(\mathrm{~V})\end{array}$ & 6 & 2(I) & 29 \\
\hline Total $\begin{array}{c}n \\
0 \%\end{array}$ & 88 & & $\begin{array}{r}56 \\
63.6\end{array}$ & & $\begin{array}{r}32 \\
36.4\end{array}$ \\
\hline
\end{tabular}


between 4.0 and $7.5 \mathrm{~mm}$, and showed no spermatogenic activity; adults (age-groups $\mathrm{I}-\mathrm{V}$ ) had testicular lengths of 4.5 to $15.4 \mathrm{~mm}$, while spermatozoids were detected from $10.0 \mathrm{~mm}$ onwards (Fig. 2, Table 1).

The breeding season for males began in December, when $25 \%$ of the individuals analysed $(N=8)$ had $\mathrm{TL}$ of more than $10.0 \mathrm{~mm}$ (Table 1). All males were sexually active in January-February. Afterwards, the percentage of sexually-active males decreased gradually towards the period of sexual repose which lasted from May-June to November (Table 1).

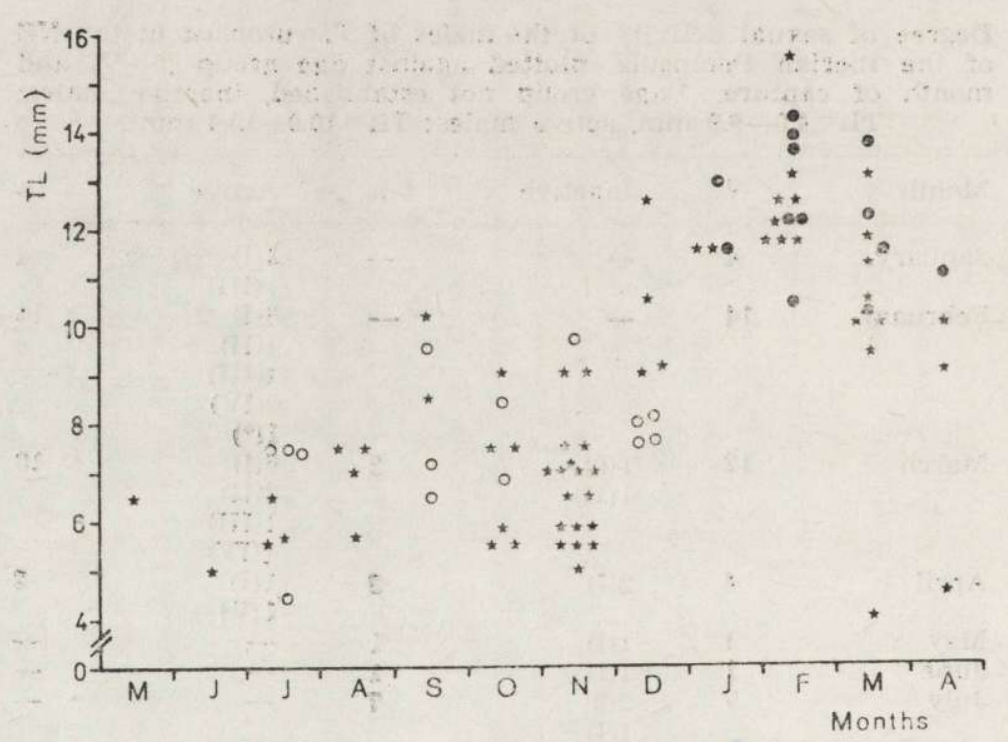

Fig. 2. Variation in the testicular length (TL) of the males of T. europaea, plotted against the month of capture. ( $\bullet$ : presence of spermatozoids; $\odot$ : absence of spermatozoids; $\star$ : lack of cytological data).

The females, too, reached sexual maturity in their second year, while those of age-group 0 had uteri without irrigation and little, or at all developed. Females of age-groups $\mathrm{I}-\mathrm{V}$ began their breeding cycle towards the end of December, reaching their maximum in FebruaryMarch. Gestations were found from January to April, while suckling females were caught between February and June. The capture of a suckling female on June 3ath implies that pregnant females could be found in May. For the females, the period of sexual repose lasted from July until November-December (Table 2).

The results show that, in the NE of the Iberian Peninsula, the breeding season of T. europaea lasts about five or six months, between December and June. Nonetheless, results from other European populations show 
a breeding season which lasts two or three months with only one litter per female (Ognev, 1928; Folitarek, 1932; Balli, 1940; Stein, 1950; Godfrey, 1956; Deanesly \& Allanson, 1967; Grulich, 1967b).

It is interesting to note the results from the present study partially coincide with those obtained by Adams $(1903,1909)$ in England, and Vericad (1970) in the Pyrenees of Huesca.

The number of embryos per litter indicates that there is no correlation between the litter-size and either the age of the female or

Table 2

Degree of sexual activity of the females of $T$. europea in the NE of the Iberian Peninsula plotted against age group $(0-V)$ and month of capture.

\begin{tabular}{|c|c|c|c|c|c|c|c|}
\hline \multirow[b]{2}{*}{ Month } & \multirow[b]{2}{*}{$N$} & \multirow[b]{2}{*}{ Inactive } & \multirow[b]{2}{*}{$n$} & \multicolumn{4}{|c|}{ Active } \\
\hline & & & & $\begin{array}{c}\text { Developed } \\
\text { and irrigated } \\
\text { uterus }\end{array}$ & Pregnant & Suckling & $n$ \\
\hline January & 4 & $1(\mathrm{IV})$ & 1 & $1(\mathrm{I})$ & $\begin{array}{l}1(\mathrm{I}) \\
1(\mathrm{~V})\end{array}$ & - & 3 \\
\hline February & 10 & $1(\mathrm{IV})$ & 1 & $\begin{array}{l}2(\mathrm{I}) \\
1(\mathrm{III}) \\
1(\mathrm{~V})\end{array}$ & $\begin{array}{l}1 \text { (II) } \\
1 \text { (III) }\end{array}$ & $\begin{array}{l}1 \text { (I) } \\
1 \text { (II) } \\
1 \text { (III) }\end{array}$ & 9 \\
\hline March & 10 & $1(\mathrm{I})$ & 1 & - & $\begin{array}{l}3 \text { (I) } \\
1 \text { (II) } \\
1 \text { (III) } \\
2 \text { (IV) }\end{array}$ & $\begin{array}{l}1 \text { (II) } \\
1 \text { (V) }\end{array}$ & 9 \\
\hline Apríl & 11 & $\begin{array}{l}1(\mathrm{I}) \\
1(\mathrm{II})\end{array}$ & 2 & $4(\mathrm{I})$ & $2(\mathrm{I})$ & $\begin{array}{l}2(\mathrm{I}) \\
1(\mathrm{~V})\end{array}$ & 9 \\
\hline May & 3 & $\begin{array}{l}1 \text { (I) } \\
1 \text { (II) }\end{array}$ & 2 & $\mathrm{I}(\mathrm{I})$ & - & - & 1 \\
\hline June & 3 & $2(0)$ & 2 & - & - & $1(\mathrm{IV})$ & 1 \\
\hline July & 7 & $\begin{array}{l}1 \text { (I) } \\
1(\mathrm{II}) \\
4(\mathrm{III}) \\
1(\mathrm{~V})\end{array}$ & 7 & - & - & - & - \\
\hline August & 6 & $\begin{array}{l}2(0) \\
3(\mathrm{I}) \\
1(\mathrm{II})\end{array}$ & 6 & - & - & - & - \\
\hline September & 6 & $\begin{array}{l}1(0) \\
4(\mathrm{I}) \\
1(\mathrm{IV})\end{array}$ & 6 & - & - & - & - \\
\hline October & 5 & $\begin{array}{l}3(\mathrm{I}) \\
1(\mathrm{II}) \\
1(\mathrm{III})\end{array}$ & 5 & - & - & - & - \\
\hline November & 21 & $\begin{array}{l}12(\mathrm{I}) \\
5(\mathrm{II}) \\
2(\mathrm{III}) \\
2(\mathrm{~V})\end{array}$ & 21 & - & - & - & - \\
\hline December & 6 & $\begin{array}{l}3(\mathrm{I}) \\
1 \text { (II) } \\
1 \text { (III) }\end{array}$ & 5 & $1(\mathrm{~V})$ & - & - & 1 \\
\hline Total $\begin{array}{c}n \\
\%\end{array}$ & 92 & & $\begin{array}{r}59 \\
64.1\end{array}$ & & & & $\begin{array}{r}33 \\
35.9\end{array}$ \\
\hline
\end{tabular}


the time of the year, as in no case were the differences significant (Table 3). The overall average number of embryos per litter for this population $(\bar{x}=3.12,2-4, n=17)$ is similar to those calculated by Adams (1903, $1909 ; \bar{x}=3.63,2-6)$ and Vericad $(1970 ; \bar{x}=2.99,2-4)$. These averages and intervals are smaller than those obtained for other European populations (Blasius, 1857: 3-5; Krumbiegel, 1929 and Ognev, 1928: 3-7; Folitarek, 1932: 3-9; Balli, 1940: $\bar{x}=4.87,2-7$; Stein, 1950: $\bar{x}=4.54$, $3-7)$. These results show that where the breeding season is short, the average number of embryos is high, whereas in places with a longer breeding period, females on average produce smaller litters, though it seems possible that they may have more litters per year. Considering the duration of pregnancy and suckling, one month and 28 days respectively (Grulich, 1967b); it must be coneluded that, during this relatively long breeding season, some females of the population studied may rear two litters, or even three, under favourable conditions. The differences noted in comparison, with other European populations can be attributed to the differing climatic conditions which are directly related to the timing of the breeding season.

More embryos were found in the left uterus than in the right (LU 1.65-RU 147, $n=17$ ) though these differences are not statistically significant.

\section{Table 3}

Variation in the number of embryos per litter and their implantation in the uterus, plotted against age group of the females (I-V) and the month of capture. (RU: right uterus; LU: left uterus).

\begin{tabular}{llcccc}
\hline & $\begin{array}{c}\text { Age } \\
\text { group }\end{array}$ & No. embr. & $\bar{x}$ embr. & $\begin{array}{r}\text { No. embr. } \\
\text { RU-LU }\end{array}$ & $\bar{x}_{\text {RU }}-\bar{x}_{\text {LU }}$ \\
\hline January & I & 3 & 3.00 & $2-1$ & $2.00-1.00$ \\
February & II & 2 & 3.25 & $1-1$ & $1.50-1.75$ \\
& II & 3 & & $2-1$ & \\
& III & 4 & & $2-2$ & \\
March & III & 4 & & $1-3$ & $1.50-1.62$ \\
& I & 3 & 3.12 & $1-2$ & \\
& I & 3 & & $1-2$ & \\
& I & 3 & & $1-2$ & \\
& II & 3 & & $2-1$ & \\
& II & 3 & & $2-1$ & \\
April & III & 3 & & $1-2$ & \\
& IV & 4 & & $2-2$ & \\
June & IV & 3 & & $2-1$ & $1.33-2.00$ \\
Total & I & 4 & 3.33 & $1-2$ & \\
\hline
\end{tabular}


Acknowledgements: The authors would like to thank Dr. J. R. Vericad, of the Pyrenean Ecology Centre (Jaca) for kindly allowing the study of moles taken from the Pyrenees of Huesca.

\section{REFERENCES}

Adams L., 1903: A contribution to our knowledge of the Mole (Talpa europaea). Mem. Proc. Manch. lit. phil. Soc., 47: 1-39 (cit. Grulich, 1967a, b). - Adams L., 1909: Some notes on the breeding habits of the common mole. Mem. Proc. Manch. lit. phil. Soc., 54: 9 (cit. Grulch, 1967a, b). - Balli A., 1940: Observazioni biologische su Talpa europaea. Rivista di Biologia (cit. Stein, 1950). - Blasius J. G., 1857 Naturgeschichte der Säugetiere Deutschlands, Braunschweig (Cit. Stein, 1950). - Deanesly R. \& Allanson M., 1967: The effects of external stimuli on reproduction. Ciba Foundation Study Group, 26: 71-80. - Folitarek S. S., 1932: Verbreitung, Biologie und Fang des Maulwurfs in der Ukranie. Bull. Soc. Nat. Moskau Biol., 41 (3-4): 235-302 (cit. Grulich, 1967a, b). - Godfrey G. K., 1956: Reproduction in Talpa europaea in Suffolk. J. Mammal., 37: 438-440. - Gosalbez J., LópezFuster $M^{\mathrm{a}}$ J. \& Durfort M., 1979: Ein neues Färbungsverfahren für Hodenzellen von Kleinsäugetieren. Säugetierkdl. Mitt., 27, 4: 303-305. - Grulich I., 1967a: Zur Methodik der Alterbestimmung des Maulwurfs, Talpa europaea L., in der Periode seiner Selbständigen Lebensweise. Zool. listy, 16: 41-59. - Grulich I., 1967b: Die Variabilität der taxonomischer Merkamle des Maulwurfs (Talpa europaea L. Insectivora) im Zusammenhang mit Alter und Geschlecht. Zool. listy, 16: 125-144 - Krumbiegel J., 1929: Säugetiere [In: Schulze P., "Biol. d. Tiere Deutschlands"] Jena (cit. Stein, 1950). - Ognev S., 1928: Mammals of eastern Europe and northern Asia. Vol. I. Insectivora and Chiroptera. Moscow (cit. Grulich, 1967a, b). - Stein G. H. W., 1950: Zur Biologie des Maulwurfs, Talpa europaea L. Bonn. zool. Beitr., 2: 97-116. - Vericad J. R., 1970: Estudio fauni'stico y bilológico de los mamiferos montaraces del Pirineo. Publ. Cent. Pirenaico Biol. Exp., 4: 231 p. Jaca.

Received 15 May 1987, Accepted 4 September 1987. 